\title{
INTERSECTION OF GENDER WITH AREA AND OCCUPATION IN ANALYSING TRAVEL BEHAVIOUR: A CASE OF RAJASTHAN, INDIA
}

\author{
Taru Saigal ${ }^{\mathrm{a}}$ \\ ${ }^{\mathrm{a}}$ Research Scholar, \\ Department of Economics and Finance, \\ Birla Institute of Technology and Science, \\ Pilani Campus, Rajasthan- 333031, \\ India.
}

\author{
Arun Kr. Vaish ${ }^{b}$ \\ ${ }^{\mathrm{b}}$ Assistant Professor, \\ Department of Economics and Finance, \\ Birla Institute of Technology and Science, \\ Pilani Campus, Rajasthan- 333031, \\ India.
}

\author{
NVM Rao ${ }^{\mathrm{c}}$ \\ ${ }^{\mathrm{c}}$ Professor, \\ Department of Economics and Finance, \\ Birla Institute of Technology and Science, \\ Pilani Campus, Rajasthan- 333031, \\ India.
}

Article DOI: https://doi.org/10.36713/epra5225

\begin{abstract}
This study examines travel behaviour of individuals differentiated with respect to gender, occupation and area using survey data collected from a city and a village in northern India. Doing this not only helps in analysing which section of the population produces the lowest carbon footprint but also in highlighting the existing difficulties faced by a certain section in choosing the most comfortable, the cheapest and the least polluting attitude towards every day travel. While the group of rural women comprises of the least frequent travellers, that of urban men make the most frequent travellers. Disparities are also observed in the mode of transport used by different sections. Urban housewives walk, rural housewives use public transport; students, irrespective of the area or gender use public transport; and a growing percentage of working people use motorized two-wheelers. Because women heavily depend on walking or using the public transport, this study points out at the need for an adequate walking infrastructure in the city along with safer and secured public transportation services for both urban and rural area. The demand for expansion of such facilities also caters to the need of curtailing carbon footprint in the region.
\end{abstract}

KEYWORDS: Travel behaviour, gender, area, occupation, India

\section{INTRODUCTION}

This paper aims to bring to notice the twofold issues of existing occupational and gender differences in transport services and the need to move towards low carbon transport. The reason why people travel owes to the existing structure of built environment (Mahadevia, 2012) and heterogeneity in population (Mahadevia \& Advani, 2016) among other factors. Most of the requirement to cover distances is either met by using non-motorized vehicles or by taking public transport.
Travel behaviour is the study of entire set of choices made by the population while making a trip. Travel behaviour is a composite term which is measured in terms of the mode of transport used by population, the frequency with which they travel, the distance to which they travel, the purpose for which they make the trip, the cost that they incur, etc. This travel behaviour of a population is influenced by a number of factors such as the type of area, land use pattern of the region, socio-economic and sociodemographic factors like income or consumption expenditure of the household or individual, the 
individual's age, gender, work status, some geographical factors, etc. This study takes into account three of these major factors influencing travel behaviour, viz. area, gender and occupation.

Gender studies on development reveal disproportionate burden of household responsibilities on women. The fact that women need to multitask affects their travel behaviour. Literature reveals that women usually travel distances which are shorter than men (Anand \& Tiwari, 2006), take modes of transport which are not only cheaper but also safer (Mahadevia \& Advani, 2016), travel less frequently, and the purpose for which they travel also differs from that of men. While there exists literature, which proves the existing gender differentials in travel behaviour in the developed world, there are not many studies in developing countries, especially those in the cities in India which highlight the travel behaviour from this perspective.

Travel behaviour also varies with variation in area type. Certain modes of transport used in rural areas are not much prevalent in urban areas and vice versa. The facility of an efficient system of public transportation lacks within villages in India. Land use pattern in a region affects the distance that the residents of that region travel. Lifestyle differences determine the purpose for which people of two regions travel. Not many studies explore the existing differences in travel behaviour between urban and rural areas of a developing country city.

Underlying differences between the frequency of travelling, distance travelled, mode of transport used by working and non-working people is the other lens through which this paper tries to study the travel behaviour disparities within and between the population of a developing country city and village.

\section{OBJECTIVES}

Using data from a large-sized city and a medium-sized village of northern India, this paper aims to examine the following: (i) to examine the current daily mobility levels and the most frequently travelled distance in a developing country city and village; (ii) to explore the impact of employment status, area and gender on different measures of travel pattern; (iii) to find out the most commonly and least frequently used mode of transport by different sections of population; (iv) to explore the different purposes for which these different groups travel daily; (v) to analyse the share of different modes of transport in daily trips for different purposes; (vi) to examine the share of different modes of transport in different distance categories; (vii) to analyse the share of frequently travelled distances for various purposes. This paper not only reaffirms the travel behaviour of women and men observed globally but also adds to the analysis of disparities in travel behaviour from other perspectives.

\section{DATA AND METHODOLOGY}

For the purpose of sampling, one rural and one urban area from within the same division in Rajasthan is selected. Jaipur city represents the urban area and the rural area is represented by Sainipura. Jaipur Municipal Corporation is divided into 8 zones. A sample proportionate to each of these zones is selected. The sample, stratified by the proportion of sex ratio and rate of literacy, comprises of 600 individuals from the city and 150 individuals from the village. Each individual in the sample is in the age group of 18 to 60 years. From each surveyed individual, data on socioeconomic characteristics, asset ownership of the household and individual information was collected.

In the case of Jaipur, the study defines a trip as a one-way intra-city trip made by an individual between the age of 18 and 60 years, within the boundaries of the city. In the case of Sainipura, definition of the same trip extends to the boundaries of district Jhunjhunu and does not remain confined to the village alone because majority of the population travels outside the village daily given the unavailability of efficient required amenities. Access and egress trips are considered part of the main trip. The mode of transport used to travel the longest distance within the trip is considered the mode of the whole trip.

The individuals have been classified into six occupational groups. Housewives, students and unemployed comprise the non-working. Working people are those who are employed in any activity, agricultural or non-agricultural and comprise of selfemployed, regular wage/salary earning and casual labour. We use Census of India (2011a) definition of work which defines it as participation in any economically productive activity with or without compensation, wages or profit. This participation can be physical and/or mental in nature, involves not only actual work but also effective supervision of work. It even includes part time help or unpaid work on farm, family enterprise or in any other economic activity.

\section{INTRODUCING THE STUDY AREA}

Rajasthan, located in northern India is the largest state by area in the country. It is the seventh largest by population having a population density of 200 square kilometres. The state is divided into seven divisions and 33 districts. Jaipur division, which is one of the seven divisions, comprises of 5 districts including Jaipur and Jhunjhunu. The study area encompasses Jaipur city within Jaipur district and Sainipura village within Jhunjhunu district.

The population of Rajasthan is $6,85,48,437$ of which $30,73,350$ are a part of Jaipur city and 1227 of Sainipura (Census of India 2011, 2011b). The sex ratio of the state is 928 , that of Jaipur city is 900 and of Sainipura is 851 (Census of India 2011, 2011b). Average literacy rate of the state is 66.1 per cent, of 
Jaipur city is 83.33 per cent and of Sainipura is 72.68 per cent (Census of India 2011, 2011b).

Jaipur which is the capital of Rajasthan is the largest city by area in the state. It is one of the top ten most populous cities in India and has a population density of 6285.41 square kilometres (Smart Cities India, 2016). Approximately 10.62 per cent of the total population resides in slums (Census of India, 2011). Hinduism is a majority religion in the city with approximately 78 per cent followers (Census of India, 2011). It is one of the earliest planned cities of modern India and is a UNESCO World Heritage Site. It is a popular tourist destination in the country and forms a part of the West Golden Triangle. The economy of Jaipur is fuelled by tourism, gemstone cutting, manufacturing jewellery and luxury textiles and information technology.

The city buses in Jaipur are operated by Jaipur City Transport Services Limited of Rajasthan State Road Transport Corporation. The service operates more than 400 regular and low-floor buses. The total number of city buses, both government and private, in 2007 was 327 (Wilbur Smith \& MoUD, 2008). Jaipur Rapid Bus Transit System (BRTS) and $150 \mathrm{~km}$ 6 lanes ring road encircling the city is proposed to solve the problem of traffic. Though Jaipur Metro has commenced its operation in the city, our study finds limited use of the same. Usage of metro reduces carbon emission per person by a significant amount. Approximately 72 per cent of the roads in the city do not have a footpath. The remaining roads where footpaths existed were mostly parked with vehicles (Times News Network, 2019). The usage of bicycle is minimal in the city.

Sainipura is a medium-sized village in Chirawa tehsil of Jhunjhunu district in Rajasthan. This village is located in an area of approximately 3 square kilometres. There is a total of 199 families residing in the village. The average literacy rate of Sainipura is higher than that of Rajasthan. Approximately 55 per cent of the total population of the village is working population (Census of India, $2011 \mathrm{~b}$ ). The village has 'kutccha' roads and lack of public transport running inside. There is lack of efficient higher education and employment-giving institutions inside the village.

In India, approximately 81 per cent of the total automobile domestic sales in 2018-19 are of motorized two-wheelers (Society of Indian Automobile Manufacturers, 2018). We observe a somewhat similar trend in Jaipur and Sainipura where the use of motorized two-wheelers is abundant and frequent.

\section{TRAVEL BEHAVIOUR IN URBAN AND RURAL RAJASTHAN}

Table 1(See Appendix) finds that the entire population of Jaipur and Sainipura does not make a trip daily. Only about 89 per cent male and 67 per cent female make a trip daily in urban area as against 85 per cent male and 47 per cent female in rural area. It is the population of rural female that travels least frequently and the population of urban male that travels most frequently. With a shift in work status from non-working to working, more people tend to make a trip daily. The proportion of non-working male population making a trip daily is more than the percentage of non-working female population, irrespective of their area of residence. Female housewives, of both urban and rural areas, account for that part of the total population which is the most unlikely to make a trip daily. From among the total male population in the study area, it is those who are unemployed who make the least regular trips.

On the whole, the population of the study area travels a distance of $0-5 \mathrm{~km}$. The entire population of Jaipur usually travels a distance of not more than 5 $\mathrm{km}$. It is only the salaried male in the city who travels a little further to a distance more than $5 \mathrm{~km}$ but less than $15 \mathrm{~km}$. The situation of travel behaviour within different occupations in Sainipura is somewhat different from that of Jaipur. While majority of the female population in the area travels short distances, it is only the students who travel a distance between $15 \mathrm{~km}$ to $25 \mathrm{~km}$. It is the population of rural male which travels the most varied distances. Male students, similar to female students, travel a distance between $15 \mathrm{~km}$ to $25 \mathrm{~km}$. It is the male earning regular salaries who travel the farthest. Even the unemployed travel distances as long as $35 \mathrm{~km}$. The group of rural male population which travels the shortest includes self-employed and casual labour. One possible explanation for the rural population travelling further than the urban population is the difference in the land use pattern (Mahadevia \& Advani, 2016, Shravani Sharma, 2019) in the two study areas. Absence of higher education institutions within the village demands students to travel a distance longer than that in the city. Male who are unemployed also search for work outside the premises of the village. Absence of any such organization within the village which provides a regular fixed source of income demands the people earning salaries to travel a distance of $35-50 \mathrm{~km}$.

According to Wilbur Smith and MoUD (2008), the modal share in Jaipur was: walking 26 per cent, cycle 13 per cent, motorized two wheeler 26 per cent, public transport 22 per cent, motorized four wheeler 4 per cent, and intermediate public transport 4 per cent. Our study finds the modal share in Jaipur on the whole is as follows: walking 27 per cent, cycle 2 per cent, motorized two-wheeler 36 per cent, motorized four-wheeler 9 per cent, tractors 0.2 per cent, public transport 25 per cent and hired taxi 1 per cent. The modal share in Sainipura according to the findings of our study is: walking 42.28 per cent, cycle 0.67 per cent, motorized two-wheeler 20.81 per cent, motorized four-wheeler 4.70 per cent and public 
transport 31.54 per cent. While the most commonly used mode of transport in Jaipur is motorized twowheeler, which in Sainipura is walking.

Table 2 (See Appendix) shows that there exist differences in modal choice by occupation, area and gender. Cycle is a mode which almost the entire population does not resort to. It is only the casual labour in urban area that uses it. The most commonly used mode of transport by urban housewives is walking and that by those in rural area is public transport. Possible explanation why housewives in rural area depend on public transport heavily is the built-in environment or land use pattern in the village where they mostly need to travel outside the village for majority of the purposes. Majority of the population of students, irrespective of the area or gender uses public transport. A growing percentage of students in urban area, especially men are beginning to use motorized two-wheelers too. The entire population of female students living in rural area uses only public transport. There exist gender differentials within this group of population of students with male students switching over to modes other than public transport. One mode of transport used by students in urban area and not in rural area is motorized four-wheelers. In both urban and rural areas, there exist gender differences in the mode of transport most commonly used by the unemployed. While female primarily depend on using the public transport, male is found to use the motorized twowheelers. In the urban area, a large section of the unemployed also depend on walking which is not the case in rural area.

There exists gender differential in modal choice among urban self-employed. While the female here depends heavily on walking, male depend on motorized two-wheelers. In the rural areas, selfemployed people, both men and women walk. Amongst the salaried people, in the rural areas there exist gender differences with men using motorized vehicles and women walking. Surprisingly, the gap between salaried men and women is bridging in urban areas with a large proportion of them using motorized vehicles. However, a large percentage of salaried women, more than men in both urban and rural areas, depend on non-motorized means of transport and public transport. Women's current mobility levels prove their higher sustainability. However, this sustainability is not arising from choice (Mahadevia \& Advani, 2016). The reason for this existing difference in modal use can be due to women's lesser access to motorized vehicles and their travelling shorter distances for a number of reasons like safety.

While the maximum proportion of female casual labour in both urban and rural areas either walks or takes the public transport, the male not only use the public transport but a growing percentage of them also uses motorized vehicles.
Table 3(See Appendix) which show proportion of different purposes for which the population travels most frequently has been divided into two broad categories of working and nonworking people. Purposes such as health, visiting relatives and friends, religious activities, sports/ recreational activities, eating out, and picking up or dropping off someone are included in the 'others' category. The major purposes for which housewives in the urban and rural area travel is not education but shopping and other activities. In the urban area, while the unemployed female travel primarily for education, the unemployed male travel for shopping and other purposes. This is in contrast to the rural area where the unemployed female travels for shopping and unemployed male for education. The major purpose for which working people travel most frequently is work and that for which the nonworking travel is education.

Table 4 (See Appendix) describes the modes of transport used for different purposes. For travelling to work, while the women in urban area either walk or use the public transport, men in the city dominantly depend on using motorized twowheelers. The population in rural area primarily depends on walking with a growing percentage of male users of motorized two-wheelers. In the urban area, female take public transport and male use motorized two-wheelers for education. In the rural area, the population depends primarily on public transport for this purpose with a rising percentage of motorized two-wheeler users. Shopping is a purpose for which the urban female usually walks and urban male usually uses motorized two-wheelers. For the same purpose rural female takes public transport and rural male uses motorized two-wheelers. For purposes other than education, shopping and work urban population and rural male use motorized twowheelers whereas rural female takes public transport. It can be noticed that for majority of the purposes women either take the public transport or walk in both urban and rural areas as against the men who depend heavily on motorized two-wheelers. One mode of transport which is used by a small percentage of overall transport is motorized fourwheelers. It mostly has male users.

Table 5(See Appendix) shows the shares of different modes of transport used for different distance categories. For a distance up to $5 \mathrm{~km}$ urban female prefer walking, urban male use motorized two-wheelers, rural female either walk or use the public transport and rural male prefer walking. For a distance more than $5 \mathrm{~km}$ up to $15 \mathrm{~km}$, urban female uses either motorized two-wheelers or public transport, urban male mostly resorts to motorized two-wheelers. The entire sample population of rural female resort to public transport for this distance, in contrast to the male who take motorized twowheelers. For distances longer than 35 km, women's 
use of motorized two-wheelers almost becomes nil and they either resort to using public transport or motorized four wheelers. While in urban area men take public transport for distances longer than $35 \mathrm{~km}$, those in the rural area still use motorized twowheelers. As distance increases, use of public transport by women also increases.

Table 6 (See Appendix) describes the most frequently travelled distance for different purposes. The analysis of purpose-wise distance travelled enables the understanding of land use pattern in the region. Sainipura is a medium-size village located in an area of approximately 3 square kilometres. Absence of efficient educational institutions nearby requires the population to travel distances longer than that travelled in the city. Women's current mobility levels prove their higher sustainability. However, this sustainability is not arising from choice (Mahadevia \& Advani, 2016).

\section{CONCLUSION}

The study area comprises of Jaipur city and Sainipura village within Jaipur division of Rajasthan in northern India. The study finds that the entire population of Jaipur and Sainipura does not make a trip daily. While the population of rural female travels least frequently, that of urban male travels most frequently. With a shift in work status from non-working to working, more people tend to make a trip daily. The population of Jaipur usually travels shorter distances than the population of Sainipura. There exist differences in modal choice by occupation, area and gender. The most commonly used mode of transport by urban housewives is walking and that by those in rural area is public transport. While female unemployed primarily depend on using the public transport, male is found to use the motorized two-wheelers.

The major purposes for which housewives in the urban and rural area travel is not education but shopping and other activities. In the urban area, while the unemployed female travel primarily for education, the unemployed male travel for shopping and other purposes. This is in contrast to the rural area where the unemployed female travels for shopping and unemployed male for education. The major purpose for which working people travel most frequently is work and that for which the nonworking travel is education. For travelling to work, while the women in urban area either walk or use the public transport, men in the city dominantly depend on using motorized two-wheelers. The population in rural area primarily depends on walking with a growing percentage of male users of motorized twowheelers. Motorized four-wheelers mostly have male users and cycle is an option that most of the population does not resort to.

For a distance up to $5 \mathrm{~km}$ urban female prefer walking, urban male use motorized two-wheelers, rural female either walk or use the public transport and rural male prefer walking. For distances longer than $35 \mathrm{~km}$, women's use of motorized two-wheelers almost becomes nil and they either resort to using public transport or motorized four wheelers. While in urban area men take public transport for distances longer than $35 \mathrm{~km}$, those in the rural area still use motorized two-wheelers. As distance increases, use of public transport by women also increases.

Women's current mobility levels prove their higher sustainability. However, this sustainability is not arising from choice. Empowerment of women is generally measured in terms of the level of educational attainment, receiving adequate health facilities, level of financial independence, ability to make independent decisions, freedom of movement among others. However, mobility, which is influenced by an effective transportation system, is a factor which influences all other indicators of women empowerment. Because women heavily depend on walking or using the public transport, this study points out at the need for an adequate walking infrastructure in the city along with safer and secured public transportation services for both urban and rural area. The demand for expansion of such facilities also caters to the need of curtailing carbon footprint in the region.

The current study examines the travel behaviour of individuals, i.e., the mode they take, the distance they travel to, the purpose for which travel, etc., differentiated from the perspective of gender, occupation and area. Doing this not only helps in analysing which section of the population produces the lowest carbon footprint but also in highlighting the existing difficulties faced by a certain section in choosing the most comfortable, the cheapest and the least polluting attitude towards every day travel.

\section{AREA FOR FURTHER RESEARCH}

This study has the following limitations: (i) the study does not differentiate between those who are self-employed, regular wage earning or are casual labours in agriculture and those in non-agriculture. (ii) It fails to evaluate the per capita trip rates in the city which help to capture the average of the total number of trips performed by an inhabitant in a day. (iii) The study also does not differentiate between different types of public transport used in the city, such as buses, autorickshaws, etc. (iv) The study also does not differentiate between those who are drivers of motorized vehicles and those who are passengers. Future studies should address these issues. 


\section{APPENDIX}

Table 1: Trip incidence and most frequently travelled distance by work status, area and sex.

\begin{tabular}{|c|c|c|c|c|c|c|c|c|}
\hline \multirow{2}{*}{ Work Status } & \multicolumn{2}{|c|}{ \% of total population making a trip daily } & \multicolumn{3}{c|}{ Most frequently travelled distance } \\
\cline { 2 - 9 } & \multicolumn{2}{|c|}{ Urban } & \multicolumn{2}{c|}{ Rural } & \multicolumn{2}{c|}{ Urban } & \multicolumn{2}{c|}{ Rural } \\
\cline { 2 - 9 } & Female & Male & Female & Male & Female & Male & Female & Male \\
\hline Housewife & 36.46 & -- & 0 & -- & $0-5 \mathrm{~km}$ & -- & $0-5 \mathrm{~km}$ & -- \\
\hline Student & 57.41 & 76.19 & 50 & 82.35 & $0-5 \mathrm{~km}$ & $0-5 \mathrm{~km}$ & $15-25 \mathrm{~km}$ & $15-25 \mathrm{~km}$ \\
\hline Unemployed & 41.18 & 36.84 & 0 & 63.64 & $0-5 \mathrm{~km}$ & $0-5 \mathrm{~km}$ & $0-5 \mathrm{~km}$ & $25-35 \mathrm{~km}$ \\
\hline Self-employed & 100 & 97.83 & 0 & 92.86 & $0-5 \mathrm{~km}$ & $0-5 \mathrm{~km}$ & $0-5 \mathrm{~km}$ & $0-5 \mathrm{~km}$ \\
\hline Salaried & 100 & 94.08 & 100 & 93.75 & $0-5 \mathrm{~km}$ & $5-15 \mathrm{~km}$ & $0-5 \mathrm{~km}$ & $35-50 \mathrm{~km}$ \\
\hline Casual labour & 100 & 94.83 & 85.7 & 77.78 & $0-5 \mathrm{~km}$ & $0-5 \mathrm{~km}$ & $0-5 \mathrm{~km}$ & $0-5 \mathrm{~km}$ \\
\hline Total & 67.02 & 88.96 & 47.06 & 85.19 & $0-5 \mathrm{~km}$ & $0-5 \mathrm{~km}$ & $0-5 \mathrm{~km}$ & $0-5 \mathrm{~km}$ \\
\hline
\end{tabular}

Source: Primary surve

Table 2: Modal share by work status, area and sex. Note: MTW= motorized two-wheeler, MFW= motorized four-wheeler, public transport= bus, autorickshaw, train, jeep.

\begin{tabular}{|c|c|c|c|c|c|c|c|c|}
\hline \multirow[t]{3}{*}{ Mode of transport } & \multicolumn{4}{|c|}{ Housewife } & \multicolumn{4}{|c|}{ Student } \\
\hline & \multicolumn{2}{|c|}{ Urban } & \multicolumn{2}{|c|}{ Rural } & \multicolumn{2}{|c|}{ Urban } & \multicolumn{2}{|c|}{ Rural } \\
\hline & Female & Male & Female & Male & Female & Male & Female & Male \\
\hline Walking & 62.50 & -- & 3.45 & -- & 22.22 & 26.19 & 0 & 17.65 \\
\hline Cycle & 0 & -- & 0 & -- & 0 & 0 & 0 & 0 \\
\hline MTW & 19.80 & -- & 17.24 & -- & 20.37 & 33.33 & 0 & 11.76 \\
\hline MFW & 7.29 & -- & 10.34 & -- & 1.85 & 4.76 & 0 & 0 \\
\hline Public transport & 8.33 & -- & 68.97 & -- & 55.56 & 35.71 & 100 & 70.59 \\
\hline Others & 2.08 & -- & 0 & -- & 0 & 0 & 0 & 0 \\
\hline Total & 100 & -- & 100 & -- & 100 & 100 & 100 & 100 \\
\hline \multirow[t]{3}{*}{ Mode of transport } & \multicolumn{4}{|c|}{ Unemployed } & \multicolumn{4}{|c|}{ Self-employed } \\
\hline & \multicolumn{2}{|c|}{ Urban } & \multicolumn{2}{|c|}{ Rural } & \multicolumn{2}{|c|}{ Urban } & \multicolumn{2}{|c|}{ Rural } \\
\hline & Female & Male & Female & Male & Female & Male & Female & Male \\
\hline Walking & 35.29 & 31.58 & 0 & 18.18 & 44.44 & 15.22 & 100 & 67.86 \\
\hline Cycle & 0 & 10.53 & 0 & 9.09 & 0 & 2.17 & 0 & 0 \\
\hline MTW & 23.53 & 47.37 & 33.33 & 45.45 & 22.22 & 56.52 & 0 & 21.43 \\
\hline MFW & 5.88 & 10.53 & 0 & 0 & 33.33 & 19.57 & 0 & 10.71 \\
\hline Public transport & 35.29 & 0 & 66.67 & 27.27 & 0 & 6.52 & 0 & 0 \\
\hline Others & 0 & 0 & 0 & 0 & 0 & 0 & 0 & 0 \\
\hline Total & 100 & 100 & 100 & 100 & 100 & 100 & 100 & 100 \\
\hline \multirow[t]{3}{*}{ Mode of transport } & \multicolumn{4}{|c|}{ Salaried } & \multicolumn{4}{|c|}{ Casual labour } \\
\hline & \multicolumn{2}{|c|}{ Urban } & \multicolumn{2}{|c|}{ Rural } & \multicolumn{2}{|c|}{ Urban } & \multicolumn{2}{|c|}{ Rural } \\
\hline & Female & Male & Female & Male & Female & Male & Female & Male \\
\hline Walking & 22.22 & 8.55 & 90.91 & 37.50 & 45.65 & 25.86 & 57.14 & 77.78 \\
\hline Cycle & 0 & 2.63 & 0 & 0 & 0 & 5.17 & 0 & 0 \\
\hline MTW & 38.10 & 56.58 & 4.55 & 62.50 & 4.35 & 29.31 & 0 & 11.11 \\
\hline MFW & 7.94 & 13.16 & 0 & 0 & 0 & 0 & 0 & 11.11 \\
\hline Public transport & 26.98 & 17.11 & 4.55 & 0 & 50.00 & 39.66 & 42.86 & 0 \\
\hline Others & 4.76 & 1.97 & 0 & 0 & 0 & 0 & 0 & 0 \\
\hline Total & 100 & 100 & 100 & 100 & 100 & 100 & 100 & 100 \\
\hline
\end{tabular}


EPRA International Journal of Multidisciplinary Research (IJMR) - Peer Reviewed Journal

Volume: 6 | Issue: 9 | September 2020 || Journal DOI: 10.36713/epra2013 || SJIF Impact Factor: 7.032 ||ISI Value: 1.188

Table 3: Trips by purpose, work status, area and sex.

\begin{tabular}{|c|c|c|c|c|c|c|c|c|c|c|c|c|}
\hline \multicolumn{13}{|c|}{ Non-working } \\
\hline \multirow[t]{3}{*}{ Purpose } & \multicolumn{4}{|c|}{ Housewife } & \multicolumn{4}{|c|}{ Student } & \multicolumn{4}{|c|}{ Unemployed } \\
\hline & \multicolumn{2}{|c|}{ Urban } & \multicolumn{2}{|c|}{ Rural } & \multicolumn{2}{|c|}{ Urban } & \multicolumn{2}{|c|}{ Rural } & \multicolumn{2}{|c|}{ Urban } & \multicolumn{2}{|c|}{ Rural } \\
\hline & Female & Male & Female & Male & Female & Male & Female & Male & Female & Male & Female & Male \\
\hline Work & 0 & -- & 0 & -- & 0 & 0 & 0 & 0 & 0 & 0 & 0 & 0 \\
\hline Education & 3.13 & -- & 0 & -- & 87.04 & 97.62 & 83.33 & 82.35 & 52.94 & 21.05 & 33.33 & 63.64 \\
\hline Shopping & 41.67 & -- & 20.69 & -- & 1.85 & 2.38 & 0 & 0 & 29.41 & 36.84 & 66.67 & 9.09 \\
\hline Others & 55.21 & -- & 79.31 & -- & 11.11 & 0 & 16.67 & 17.65 & 17.65 & 42.11 & 0 & 27.27 \\
\hline Total & 100 & -- & 100 & -- & 100 & 100 & 100 & 100 & 100 & 100 & 100 & 100 \\
\hline \multicolumn{13}{|c|}{ Working } \\
\hline \multirow{3}{*}{\multicolumn{3}{|c|}{ Purpose }} & \multicolumn{10}{|c|}{ Self-employed, Salaried, Casual Labour } \\
\hline & & & \multicolumn{5}{|c|}{ Urban } & \multicolumn{5}{|c|}{ Rural } \\
\hline & & & \multicolumn{2}{|c|}{ Female } & & \multicolumn{2}{|c|}{ Male } & \multicolumn{3}{|c|}{ Female } & \multicolumn{2}{|c|}{ Male } \\
\hline \multicolumn{2}{|c|}{ Work } & & \multicolumn{2}{|c|}{100} & & \multicolumn{2}{|c|}{100} & \multicolumn{3}{|c|}{100} & \multicolumn{2}{|c|}{100} \\
\hline \multicolumn{2}{|c|}{ Education } & & \multicolumn{2}{|c|}{0} & & \multicolumn{2}{|c|}{0} & \multicolumn{3}{|c|}{0} & \multicolumn{2}{|c|}{0} \\
\hline \multicolumn{2}{|c|}{ Shopping } & & \multicolumn{2}{|c|}{0} & & \multicolumn{2}{|c|}{0} & \multicolumn{3}{|c|}{0} & 0 & \\
\hline & ers & & $\mathrm{C}$ & & & 0 & & & 0 & & 0 & \\
\hline & tal & & 10 & & & 10 & & & 100 & & 10 & \\
\hline
\end{tabular}

Source: Primary survey

Table 4: Modal share by purpose, area and sex. Note: MTW= motorized two-wheeler, MFW= motorized four-wheeler, public transport= bus, autorickshaw, train, jeep.

\begin{tabular}{|c|c|c|c|c|c|c|c|c|}
\hline \multirow[t]{3}{*}{ Mode of transport } & \multicolumn{4}{|c|}{ Work } & \multicolumn{4}{|c|}{ Education } \\
\hline & \multicolumn{2}{|c|}{ Urban } & \multicolumn{2}{|c|}{ Rural } & \multicolumn{2}{|c|}{ Urban } & \multicolumn{2}{|c|}{ Rural } \\
\hline & Female & Male & Female & Male & Female & Male & Female & Male \\
\hline Walking & 33.05 & 13.67 & 83.33 & 60.38 & 20 & 23.08 & 0 & 9.52 \\
\hline Cycle & 0 & 3.13 & 0 & 0 & 0 & 2.56 & 0 & 0 \\
\hline MTW & 23.73 & 50.39 & 3.33 & 32.08 & 21.67 & 43.59 & 16.67 & 28.57 \\
\hline MFW & 6.78 & 11.33 & 0 & 7.55 & 0 & 2.56 & 0 & 0 \\
\hline Public transport & 33.90 & 20.31 & 13.33 & 0 & 58.33 & 28.21 & 83.33 & 61.90 \\
\hline Others & 2.54 & 1.17 & 0 & 0 & 0 & 0 & 0 & 0 \\
\hline Total & 100 & 100 & 100 & 100 & 100 & 100 & 100 & 100 \\
\hline \multirow[t]{3}{*}{ Mode of transport } & \multicolumn{4}{|c|}{ Shopping } & \multicolumn{4}{|c|}{ Others } \\
\hline & \multicolumn{2}{|c|}{ Urban } & \multicolumn{2}{|c|}{ Rural } & \multicolumn{2}{|c|}{ Urban } & \multicolumn{2}{|c|}{ Rural } \\
\hline & Female & Male & Female & Male & Female & Male & Female & Male \\
\hline Walking & 39.66 & 15.42 & 4.55 & 14.29 & 31.82 & 8.93 & 33.55 & 33.33 \\
\hline Cycle & 0 & 3.33 & 0 & 7.14 & 0 & 3.57 & 0 & 0 \\
\hline MTW & 28.69 & 53.75 & 18.18 & 40.00 & 46.97 & 53.57 & 10.97 & 66.67 \\
\hline MFW & 12.24 & 16.25 & 0 & 5.71 & 18.18 & 31.55 & 3.23 & 0 \\
\hline Public transport & 15.61 & 10.42 & 77.27 & 32.86 & 3.03 & 0 & 50.97 & 0 \\
\hline Others & 3.80 & 0.83 & 0 & 0 & 0 & 2.38 & 1.29 & 0 \\
\hline Total & 100 & 100 & 100 & 100 & 100 & 100 & 100 & 100 \\
\hline
\end{tabular}


Table 5: Modal share by distance categories, area and sex. Note: MTW= motorized two-wheeler, MFW= motorized four-wheeler, public transport= bus, autorickshaw, train, jeep.

\begin{tabular}{|c|c|c|c|c|c|c|c|c|}
\hline \multirow[t]{3}{*}{ Mode of transport } & \multicolumn{4}{|c|}{$0-5 \mathrm{~km}$} & \multicolumn{4}{|c|}{$5-15 \mathrm{~km}$} \\
\hline & \multicolumn{2}{|c|}{ Urban } & \multicolumn{2}{|c|}{ Rural } & \multicolumn{2}{|c|}{ Urban } & \multicolumn{2}{|c|}{ Rural } \\
\hline & Female & Male & Female & Male & Female & Male & Female & Male \\
\hline Walking & 57.07 & 35.37 & 44.64 & 77.50 & 0 & 0 & 0 & 0 \\
\hline Cycle & 0 & 4.08 & 0 & 0 & 0 & 2.73 & 0 & 0 \\
\hline MTW & 17.56 & 43.54 & 7.14 & 15.00 & 37.74 & 63.64 & 0 & 100 \\
\hline MFW & 1.95 & 5.44 & 1.79 & 2.50 & 16.98 & 15.45 & 0 & 0 \\
\hline Public transport & 22.44 & 11.56 & 46.43 & 5.00 & 39.62 & 16.36 & 100 & 0 \\
\hline Others & 0.98 & 0 & 0 & 0 & 5.66 & 1.82 & 0 & 0 \\
\hline Total & 100 & 100 & 100 & 100 & 100 & 100 & 100 & 100 \\
\hline \multirow[t]{3}{*}{ Mode of transport } & \multicolumn{4}{|c|}{$15-25 \mathrm{~km}$} & \multicolumn{4}{|c|}{$25-35 \mathrm{~km}$} \\
\hline & \multicolumn{2}{|c|}{ Urban } & \multicolumn{2}{|c|}{ Rural } & \multicolumn{2}{|c|}{ Urban } & \multicolumn{2}{|c|}{ Rural } \\
\hline & Female & Male & Female & Male & Female & Male & Female & Male \\
\hline Walking & 0 & 0 & 0 & 20.83 & 0 & 0 & 0 & 10.00 \\
\hline Cycle & 0 & 4.00 & 0 & 4.17 & 0 & 0 & 0 & 0 \\
\hline MTW & 29.41 & 36.00 & 20.00 & 37.50 & 25.00 & 53.85 & 66.67 & 20.00 \\
\hline MFW & 17.65 & 20.00 & 20.00 & 4.17 & 25.00 & 0 & 0 & 20.00 \\
\hline Public transport & 52.94 & 36.00 & 60.00 & 33.33 & 50.00 & 46.15 & 33.33 & 50.00 \\
\hline Others & 0 & 4.00 & 0 & 0 & 0 & 0 & 0 & 0 \\
\hline Total & 100 & 100 & 100 & 100 & 100 & 100 & 100 & 100 \\
\hline \multirow[t]{3}{*}{ Mode of transport } & \multicolumn{4}{|c|}{$35-50 \mathrm{~km}$} & \multicolumn{4}{|c|}{$>50 \mathrm{~km}$} \\
\hline & \multicolumn{2}{|c|}{ Urban } & \multicolumn{2}{|c|}{ Rural } & \multicolumn{2}{|c|}{ Urban } & \multicolumn{2}{|c|}{ Rural } \\
\hline & Female & Male & Female & Male & Female & Male & Female & Male \\
\hline Walking & 0 & 0 & 0 & 0 & 0 & 0 & 0 & 0 \\
\hline Cycle & 0 & 0 & 0 & 0 & 0 & 0 & 0 & 0 \\
\hline MTW & 0 & 0 & 0 & 100 & 0 & 25.00 & 0 & 100 \\
\hline MFW & 0 & 15.38 & 50.00 & 0 & 0 & 12.50 & 50.00 & 0 \\
\hline Public transport & 100 & 84.62 & 50.00 & 0 & 100 & 62.50 & 50.00 & 0 \\
\hline Others & 0 & 0 & 0 & 0 & 0 & 0 & 0 & 0 \\
\hline Total & 100 & 100 & 100 & 100 & 100 & 100 & 100 & 100 \\
\hline
\end{tabular}

Table 6: Trip purpose by distance categories, area and sex.

\begin{tabular}{|c|c|c|c|c|c|c|c|c|}
\hline \multirow[t]{3}{*}{ Distance } & \multicolumn{4}{|c|}{ Work } & \multicolumn{4}{|c|}{ Education } \\
\hline & \multicolumn{2}{|c|}{ Urban } & \multicolumn{2}{|c|}{ Rural } & \multicolumn{2}{|c|}{ Urban } & \multicolumn{2}{|c|}{ Rural } \\
\hline & Female & Male & Female & Male & Female & Male & Female & Male \\
\hline $0-5 \mathrm{~km}$ & 70.34 & 44.71 & 100 & 83.02 & 62.71 & 46.67 & 16.67 & 33.33 \\
\hline $5-15 \mathrm{~km}$ & 21.19 & 35.29 & 0 & 1.89 & 25.42 & 37.78 & 0 & 4.76 \\
\hline $15-25 \mathrm{~km}$ & 5.08 & 7.84 & 0 & 1.89 & 6.78 & 8.89 & 66.67 & 23.81 \\
\hline $25-35 \mathrm{~km}$ & 1.69 & 4.71 & 0 & 3.77 & 0 & 2.22 & 16.67 & 38.10 \\
\hline$>35 \mathrm{~km}$ & 1.70 & 7.46 & 0 & 9.43 & 5.08 & 4.44 & 0 & 0 \\
\hline \multirow[t]{4}{*}{ Total } & 100 & 100 & 100 & 100 & 100 & 100 & 100 & 100 \\
\hline & \multicolumn{4}{|c|}{ Shopping } & \multicolumn{4}{|c|}{ Others } \\
\hline & \multicolumn{2}{|c|}{ Urban } & \multicolumn{2}{|c|}{ Rural } & \multicolumn{2}{|c|}{ Urban } & \multicolumn{2}{|c|}{ Rural } \\
\hline & Female & Male & Female & Male & Female & Male & Female & Male \\
\hline $0-5 \mathrm{~km}$ & 78.26 & 87.50 & 87.50 & 100 & 79.03 & 62.50 & 79.17 & 100 \\
\hline $5-15 \mathrm{~km}$ & 15.22 & 12.50 & 0 & 0 & 9.68 & 25.00 & 4.17 & 0 \\
\hline $15-25 \mathrm{~km}$ & 6.52 & 0 & 0 & 0 & 6.45 & 12.50 & 4.17 & 0 \\
\hline $25-35 \mathrm{~km}$ & 0 & 0 & 12.50 & 0 & 3.23 & 0 & 4.17 & 0 \\
\hline$>35 \mathrm{~km}$ & 0 & 0 & 0 & 0 & 1.61 & 0 & 8.33 & 0 \\
\hline Total & 100 & 100 & 100 & 100 & 100 & 100 & 100 & 100 \\
\hline
\end{tabular}




\section{REFERENCES}

1. Anand, A., \& Tiwari, G. (2007), "A Gendered Perspective of the Shelter - Transport Livelihood Link: The Case of Poor Women in Delhi," vol.26, no. 1, p.p: 63-80. https://doi.org/10.1080/01441640500175615

Census of India (2011), "Jaipur City Census 2011 data." Retrieved April 14, 2020, from https://www.census2011.co.in/census/city/77jaipur.html

2. Census of India (2011a), "Main Workers, Marginal Workers, Non-Workers and those Marginal Workers, Non-Workers seeking/available for work classified by Age and Sex, 2011." Retrieved May 19, 2020, from https://data.gov.in/resources/main-workersmarginal-workers-non-workers-and-thosemarginal-workers-non-workers-27

3. Census of India (2011b), "Sainipura Population Jhunjhunun, Rajasthan." Retrieved May 19, 2020, from https://ww.census2011.co.in/data/village/71153sainipura-rajasthan.html

4. Mahadevia, D. (2012), "Decent Work in Ahmedabad: An Integrated Approach," ILO Asia-Pacific Working Paper Series, June.

5. Mahadevia, D., \& Advani, D. (2016), "Gender Differentials in Travel Pattern - The Case of a Mid-Sized City, Rajkot, India," Transportation Research Part D: Transport and Environment, vol. $\quad 44, \quad$ p.p: 292-302. https://doi.org/10.1016/j.trd.2016.01.002

6. Ministry of Housing and Urban Affairs, Government of India (2016), "Smart City Profile Jaipur," India Smart City Profile.

7. Shravani Sharma. (2019), "Factors Influencing Travel Behavior and Mode Choice," Retrieved May 19, 2020, from https://www.geospatialworld.net/blogs/factorsinfluencing-travel-behavior-and-mode-choicel

8. Society of Indian Automobile Manufacturers (2014), "Automobile Domestic Sales Trends," Retrieved April 20, 2020, from http://www.siam.in/statistics.aspx?mpgid $=8 \& p g i$ dtrail $=14$

9. Times News Network (2019), "72\% of City Roads Devoid of Footpath: Study," Times of India, Retrieved April 14, 2020, from https://timesofindia.indiatimes.com/city/jaipur/72 -of-city-roads-devoid-of-footpathsstudy/articleshow/67518477.cms

10. Wilbur Smith Associates and Ministry of Urban Development (2008), "Study on Traffic and Transportation-Policies and Strategies in Urban Areas in India," Ministry of Urban Development, Government of India, p.p: 1-149. 